УДК: 903.27(571.15);711.52:902

ББК: 63.4(3)

A43

DOI: $10.18688 /$ aa $188-8-67$

Paolo Gardelli

\title{
Stabiae and the Beginning of European Archaeology: From Looting to Science
}

At the beginning of the $15^{\text {th }}$ century, the recovery of ancient classical tradition through the study of literary works and written sources created ideal conditions for the birth of the first great art collections such as those of the Medici in Florence, the Gonzagas in Mantua, Sixtus IV and Julius II in Rome, and Cardinal Grimani in Venice ${ }^{1}$. In the beginning, public and private collections were fueled by chance finds, by the plundering of ancient buildings, or by the import of antiquities from the Eastern Mediterranean, and occasional excavations, such as those promoted by the Farnese family in Rome. In the $17^{\text {th }}$ and $18^{\text {th }}$ centuries, large-scale antique dealers such as Bernard de Montfaucon or the Count de Caylus assembled huge catalogues of ancient artworks and artifacts which were available to scholars; these catalogues were always illustrated and commented, however, were not included in a historical narrative of art history [5, p.4]. Despite the wide interest, until the first decades of the $18^{\text {th }}$ century knowledge of antiquity was linked almost exclusively to literary, epigraphic, and numismatic sources as well as to a limited number of ancient monuments that remained commonly accepted from the Renaissance to the beginning of the $18^{\text {th }}$ century. Therefore, when in the first half of the $18^{\text {th }}$ century excavations began to reveal paintings, sculptures, mosaics, instrumenta domestica, and the public and private buildings of Herculaneum, Pompeii and Stabiae, buried by the eruption of Vesuvius in $79 \mathrm{AD}$, the influence of new discoveries on Italian and European culture of the time was of extraordinary importance, leading to a profound change in the taste for antiquity and relation to it.

The rediscovery of Stabiae began June 7, 1749 when carrying out excavations near the bridge of San Marco, in the then territory of Gragnano, some artifacts were found that convinced King Charles of Bourbon to undertake an initial exploration campaign on the Varano hill that would end fourteen years later [29, p.3]. During the first year the excavations were conducted by an officer of the Neapolitan Army Corps, Rocque Joaquin de Alcubierre. A well-disciplined engineer, but completely devoid of any form of classical erudition, Alcubierre managed the excavation without any coherent method, promoting the construction of trenches and tunnels,

1 I would like to thank my colleague Taylor James Layton of Restoring Ancient Stabiae Foundation (RAS) who provided the translation of this article into English. Special thanks to Prof. Thomas Noble Howe, RAS General Coordinator, for his invaluable assistance and to Dr. Giovanna Bonifacio, Director of the site of Stabia, for her willingness in granting permission for new researches. 
ordering the backfilling of already investigated areas, with disregard for damaging any ancient structures and demonstrating disinterest for drafting maps and floor plans of the investigated buildings. This approach therefore precluded the production at Stabiae, but even more so in Pompeii and Herculaneum, of any form of topographical knowledge of the ruins that were gradually being unearthed. The main objective of the excavation was then the systematic plunder of the ancient structures through detachment of the finest wall paintings, the pavements of tesselatum and opus sectile, and all the portable furniture that the diggers came across in order to form the collection of antiquities of the sovereign.

In this perspective, all the self-congratulatory masterpieces that were part of the royal collections therefore became subserviant to the political programme of the sovereign to celebrate his personal prestige and dynastic authority and contributed to the fulfilment of the legitimacy of the new reign of Charles, by ideally placing him in the context of the glorious ancient classical tradition [4, pp. 56-71; 25, p. 21]. As of July 1750, Alcubierre was joined by the Swiss officer Karl Jacob Weber in the role of junior engineer. In the first years at Stabia, Weber did not record significant changes in the methodological approach to the excavation compared to the modus operandi of his immediate superior, as his subordinate position limited his decision making authority. The excavations in fact continued to be conducted through the usual procedure of temporary occupation of private lands, the digging of trenches, the removal of any materials that could meet the taste of the sovereign, the destruction of paintings that were in a bad state of preservation, and finally backfilling the entire excavated area.

The selection and therefore the fate of the artifacts to be included in the royal collection was up to the Roman painter, Camillo Paderni, who was appointed "Custode" of antiquities in 1752. The judgement of the latter determined the preservation of an artifact or its total disintegration (Ill. 97), and in fact, if the paintings at the time of discovery showed imperfections or did not meet the current taste, Paderni instead of ordering just their backfilling, demanded the total destruction for fear of resale by third parties on the black market or that they would be used as templates for the production of fakes in the thriving illegal market in Rome [25, p.21]. The interest of Paderni regarding the paintings had turned almost exclusively to figural motifs of III and IV Style and avoided almost completely fictive painted marble, decorative motifs and architectural elements of the I and II Style, which were therefore left in situ [2, pp. 52-53; 3 , pp. 101-103]. The excavators were in fact searching for small landscape and still life paintings, mythological scenes that lent themselves well, as antiquarian Ridolfino Venuti reported to be used to make "tanti bei Quadri per la Galleria del Re" [3, pp. 101-102; 14, p. 34; 26, p.23]. The operations of detaching paintings, mosaics, and crustae marmorae were entrusted to Joseph Canart, a sculptor and restorer probably of Flemish origin, but of Roman education, who was called to Naples in 1739 to deal with the restoration of the sculptures that were being retrieved from Herculaneum, and in 1743 he was appointed "Statuario del Re" [14, p. 15]. Canart almost certainly played a coordinating role, in the sense that the operation of cutting and extraction of the paintings, mosaics and marble slabs was apparently systematically entrusted to his employees, mostly marble workers and young sculptors, which required great technical skill to avoid chipping or breaking the walls, the layers of plaster or the pavements of the floor [13, pp. 119, 121; 14, p. 17]. There was never any reference to their identity made in the excavation documents, but showed them generically "uno de los jobenes de Canart" or "tagliato 
dalli giovani di Canart in Stabia", or "a Stabia si tagliano dai giovani di Canart i due pavimenti di musaico" [29, pp. 79, 230, 278].

Thanks to the archaeological and archival investigations promoted over the last sixty years $^{2}$, it is possible to discover new aspects not only on Roman Stabia and its villas, but they also made it possible to shed more light on the dynamics of excavation in the $18^{\text {th }}$ century and to understand the original context of many of the artifacts found during the century that are now preserved at the National Archaeological Museum of Naples ${ }^{3}$. In this regard, I would like to point out that the recent and valuable contribution of the State Hermitage Museum with the excavation at Villa Arianna has provided new data, helping to decisively clarify not only the actual layout of the thermal sector, its building phases and its decoration, but also revealed new important aspects of the Bourbon excavation phases in Stabia (Ill. 99) [17; 18; 19]. The traces of the movements of the $18^{\text {th }}$ century diggers are visible everywhere both in Villa San Marco and Villa Arianna and testy to not only to the many breaches that were made in the walls to move from one chamber to another (Ill. 101), or from the several voids left in the walls and floors as a result of the detachment of decorative motifs, but also by numerous bits of epigraphic evidence left by the workers themselves on the painted surfaces [32, pp. 353-354, 358-360]. The situation is slightly different for the personnel involved in the excavation operations from the young unidentified employees of Canart. In fact, besides the names of the supervisors Giuseppe Corcoles and Gioacchino Perez Conde, the names of the master builders Antonio and Pasquale Scognamiglio, Stefano Caruso, the Corporal Michele de Çiria and the worker Giuseppe Prechia, were already known by excavation reports. Some graffiti still visible along the walls of Villa San Marco recall the daily activity of another Scognamiglio, one Pietro, as well as the presence of workers Carmine and Pecchia Giuseppe. The Bourbon graffiti found at Stabia are also valuable evidence of the deep religiosity of the workers involved in the excavations, such as the one found in the entrance porch in Villa San Marco which reads "Sia benedeta la macolata cogeziona del beata vergine Maria", and of the strong superstitions that accompanied them in their daily activities, as the many five- and six-pointed stars with apotropaic value found in Villa San Marco and Villa Arianna would indicate, some of which are engraved in the vicinity of the passage holes in the walls. There are even depictions of boats, human figures, quadrupeds and birds, but also testimonies of brief moments of leisure.

Despite the fact that the excavation journals demonstrate the lack of interest on the part of the court to provide any form of protection to what was discarded and abandoned in situ, exemplary punishments could strike the worker who had been guilty of theft of antiquities: "sarà ipso facto condannato a sette anni di galera e prima frustato per mano del ministro dell'alta giustizia". But even worse penalties affected those condemned to forced labour. In fact, if one of them had covered up "anche la più minima cosa di quelle che si ritrovano, sarà subito condannato in galera in vita sulle galere di Malta e frustato come sopra" [29, p. 163]. In the Bourbon kingdom very tight control was exercised over the archaeological heritage, and the same approach

2 The rediscovery of Stabiae occurred in the 1950s thanks to the excavations promoted by Libero d'Orsi [8; 15]. For recent investigations in the ancient urban settlement see [28], for Villa San Marco [6;16; 27], for Villa Arianna $[7 ; 9 ; 17 ; 18 ; 20 ; 21 ; 30]$ and for Villa del Pastore $[10 ; 31]$.

3 To know more about the origins of the wall paintings and objects found during the 1700s in Stabiae and now displayed at MANN, see [23, pp. 233-253]. 
applied to the excavation campaigns at Stabiae, as at Herculaneum and Pompeii. Discoveries were jealously safeguarded, so that the privileged visitors to the Portici museum were not even allowed to draw or take notes of the exhibits, since their publication was a royal privilege. This conduct earned the sovereign of Naples much criticism from circles of antique dealers and across culture in Europe, among whom that of Winckelmann, who in the noted "Lettera al Conte di Brühl", satirized the total absence of skills on the part of Alcubierre [12, p. 137; 34, p. 148].

The story of the excavations is also the history of progressive establishment of a technique and a working method, which has no real analogy to preceding experience. Despite the proven system to remove individual figural motifs from the walls, which as a consequence involved the loss of complex decorations, the diggers over the years began to realize the importance of the pictorial context [1, pp. 23-24; 3, pp. 101-102]. For example, the excavation bulletin dated October 20,1754, explains that Paderni was asked to go to the excavation of Villa San Marco "para

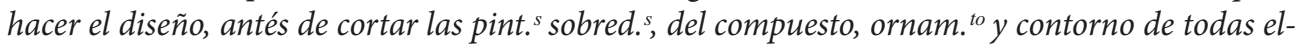
las, por ser cosa que lo merece", or a few years later, on July 15, 1759, after Weber ran into a space where "las 4 paredas presenta tanta architectura y adornos y cornices, sobre las cuales se cuenten 15 figuras", he counseled with great foresight, to have them drawn or "cortarlas muy grandes con toda architectura y muchas figuras dentro una sola pintura, que sirve mejor por la historia cuando se vee la situacion y circumstancias de las mismas figuras" [29, pp. 32, 94]. In a note of November 12, 1763, to Alcubierre, Tanucci blamed Paderni very harshly for the destruction of some wall paintings; however, at the same time he did not forbid that they be abandoned but merely declared that the judgement to destroy or abandon the findings was not up to Paderni but to the king himself $[29$, p. 206]. Something was obviously changing. Surely one of the key figures in this new methodological approach in conducting the work was Weber, who, from the end of the 1750s until his death in 1764, began important activities on the development of detailed architectural drawings. Between 1759 and 1760 he in fact brought them to completion and delivered them to the court of Naples "tres plantas de los edificios subterraneos de la antigua Estabia" [29, p. 121], dealing with the plans of the urban center of Stabiae and of what we now know as Villa San Marco (Ill. 100), Villa del Pastore and Villa Arianna. Floor plans, given the very high level of precision, are still indispensable for any archaeological investigations and of fundamental importance for the understanding of ancient Stabiae. But the intuition that most of all transformed the excavation technique, giving the sense of the actual scope of Weber's foresight, was his proposal to favour the systematic unearthing of the buildings and their display on site, as it can be seen clearly from his writing of November 19, 1761: "mayor gloria saria por el Reyno y mas satisfacion por los extranjeros letrados el poder observar alguna reliquia de edificio antiguo en su sitio" [29, p. 164].

For the first time the importance of considering the ancient structures and the urban fabric as a document was through which it became possible to interpret transformations of art and architecture in relation to their context percieved. Unfortunately, with regards to Stabia his proposal was not accepted and the ancient structures were accordingly reinterred. However, when in 1763, during the excavation of the necropolis of Porta Ercolano, it was possible to associate the hill of Civita with the ancient city of Pompeii, thanks to the inscription discovery of Titus Suedius Clemens, in which it made explicit mention of the Res Publica Pompeianorum, 
the minister Tanucci, convinced by the ideas of Weber, ordered that the ruins were no longer to be reinterred.

During the 50 s of the $18^{\text {th }}$ century the same King Charles decided to give a completely different impression of the excavations that had been started with the singular intent of self-celebration, in 1755 decreed the establishment of the Accademia Ercolanese in order to control, study and to more rigorously disseminate the results of the investigations in the three Vesuvian sites [11, p.33]. For its organization the Neapolitan court was inspired by existing models, already arisen in Italy and Europe, even before the Ercolanese, several societies and academies for scholars and antiquarians, such as the Académie des Inscriptions et Belles-Lettres founded in 1663 in France under the reign of Louis XIV, or the Society of Antiquaries and the Society of Dilettanti, both constituted in London in 1707 and 1734 respectively, while in Italy the creation of the Accademia Etrusca of Cortona dates back to 1727, the reference model for the Bourbons, and from 1735 the Società Colombaria of Florence. In 1757 the Accademia Ercolanese published the first volume of the work entitled "Le antichità di Ercolano esposte", whose recordings contributed fundamentally to the blooming of the neoclassical taste in European culture. Despite its name, in the eight volumes published between 1757 and 1792 it not only included the masterpieces found in the excavations at Herculaneum, but also the paintings and the important objects from Stabiae and Pompeii. Therefore, some of the Stabiae paintings, including the socalled Flora and the Seller of Cupids, became, thanks to the diffusion of the volumes, the definitive models for neoclassical culture (Ill. 98). It should be stated that the main limitation of the eight volumes of the "Le antichità di Ercolano esposte" was the total absence of a direct reference to individual buildings of origin of archaeological material or to the urban context of discovery. The work, as a whole, was still in continuity with the antiquarian tradition and the systematic looting activities for political prestige rather than the result of a serious scientific documentation. Once again the ideas of Weber were well ahead of their time. In fact, he forwarded to Tanucci on October 18, 1759 his proposal to proceed with the publication of the third volume of "Antichità di Ercolano", where he would have illustrated the plan layouts of the buildings excavated at Herculaneum, Pompeii and Stabiae, accompanied by indications referring to the context of discovery of each painting or object [24, pp. 177-198, 296-319; 29, pp. 108-109] ${ }^{4}$. From a communication that Tanucci forwarded to the sovereign it is clear that he supported the admission of Weber as a member of the Accademia and encouraged the publication of his work [29, pp. 131-132]. From a historical and archaeological point of view, the true value of the work, unfortunately never published, is in fact, that this is a clear testimony of the will of Weber to become a promoter of a new methodological approach outlining very clearly the transition from interest for the object as such to that for its documentary value. It is also an evidence for a change in perspective which very slowly came to consider the archaeological artifact as research material and, consequently, as a source of knowledge. The accuracy of the plans of Weber impressed Winckelmann who had a chance to see them during his first stay in Naples in 1758. He spoke of them in enthusiastic terms in the letter that he wrote to the Counselor Giovanni Ludovico Bianconi: "mi è riuscito finalmente di vedere le piante delle scavazioni sotterranee fatte con esattezza incredibile dall'ingegnere regio" [33, p. 85].

4 A summary of the manuscript has been published by Michele Ruggiero [29, pp. 137-144, Tav. I-IV]. 
The second excavation campaign was undertaken from 1775 until 1782, under the leadership of the now more than seventy-year old Alcubierre. By his side was the architect Francesco La Vega, who had replaced Weber after his death [22, pp. 9-15]. From the first months of service La Vega diligently collected all the material produced in preceding decades by Weber and Alcubierre and submitted constant updates to it to accurately reconstruct the history of the excavations and to permit the punctual illustration of the finds. Thanks to his rigorous method and its insights, a change came about in the history of excavation at Stabiae, as well as at Herculaneum and even more so in Pompeii where, in order to flesh out the research done up to that moment and make at least one part of the city visitable, he promoted, expanding the previous excavations of Alcubierre, a new campaign of surveys along the Via dei Sepolcri. The great merit of La Vega was to introduce two new concepts for the first time into the by now almost completely superseded antiquarian tradition of the Neapolitan court, which forever changed the nascent discipline of archaeology: organic research and contextualization of the ancient. This new approach which slowly took hold in the Bourbon kingdom was the reflection of an important change taking place in European antiquarian culture of the second half of the $18^{\text {th }}$ century. This was the time when the intellectuals felt more need to enjoy direct observation of monuments and the ruins of ancient buildings, and no longer studied objects only in a book or observed in their singularity, but seen in their landscape or in the historical and archaeological complex [5, p.8].

In May $1775 \mathrm{La}$ Vega tried to also apply the same methodological approach to Stabia that he had already used for Pompeii [29, p. 225]. One of the priorities of this second campaign, as reported by La Vega himself, was in fact to get his hands on all documents produced until 1762 by those who preceded him, while simultaneously promoting new excavations with the intent of "legare assieme varie piante di edifici scavati in distinti tempi nella citta di Stabia" in order to supplement and update the site plan [29, p. 262]. In the seven years at Stabia La Vega resumed excavations in some villas already partially excavated previously, those that are now known as Villa del Pastore, Villa Arianna and Second Complex. He also extended the research to a large number of villae rusticae of ager stabianus and developed precise plans and documentations of the excavations for each of them [29, Tav. V-XIX]. However, what he could not accomplish, unlike what was done at Pompeii, was to persuade the court to maintain the visibility of the excavated buildings and avoid their backfilling. Despite the excellent documentation, the excavation of Stabia continued, even in this second campaign of excavations, working with the usual technique of digging and backfilling [29, p. 260].

The final backfill and abandonment of the area took place in December of 1782, yielding to the result that Stabiae, unlike Pompeii and Herculaneum, failed to establish for itself as a preferred destination for travellers on the Grand Tour. In my view, there were three reasons that led the Neapolitan court to make this decision. First, it must be remembered that from the earliest years of excavations the landowners of the Varano plateau, seeing their yield decrease in favour of continuation of the investigations, sent numerous protests to the king: "Con ordine in data 5 del corrente si servi V. E. rimettermi la supplica, che aggiunta restituisco, di D. Ignazio Girace, nella quale dimanda di togliersi lo scavamento che si faceva in una sua masseria nel tenimento di Castellamare e che gli vengano pagati i danni" [29, p. 260]. Therefore, the court, during the years of sanctioned investigations at Stabia, preferred to not extensively excavate for a prolonged pe- 
riod of time in order to allow quick backfilling and restoration of land to its legitimate owners. The second reason, which compliments the previous one, is that, in about the twenty-two years of excavations at Varano, they recorded throughout the area paintings and artifacts of great artistic value, but the Bourbon court considered these findings singular episodes of an occasional nature, so as not to justify excavations of greater extent and longevity. However, the reason that most of all influenced the choice first of Charles and later Ferdinand IV not to undertake extensive excavations here was the extreme dispersion of archaeological material, a problem which, after more than two and a half centuries from the first excavations, still limits the real understanding of the archaeological site. With the exception of the small urban nucleus, the area of Stabia has always been characterized by the existence of numerous leisure villas arranged along the brow of the hill and even presence of numerous rustic villas distributed over a vast area that goes from Castellammare to Gragnano and to Pompeii. La Vega was aware of the same issues when realized the impossibility of implementing a comprehensive excavation like the undertaking in Pompeii and repeatedly expressed in negative terms to the continuation of the surveys at Stabia and its territory "Io mi trovo necessitato a dirli, pel buon servizio del Re, che il volere continuare in Stabia lo scavo è un perdere quasi certamente il tempo" [29, p. 239]. Therefore, despite the abundance of discoveries, the name and fame of Stabiae for about two centuries until its rediscovery in 1950, thus remained more related to the prestige of the individual masterpiece and the quality of some of its wall paintings, whose fame was widespread.

In conclusion, I would like to focus on what is now the most widespread preconception, one that sees the entire period of Bourbon archaeology as a period of primitive and brutal techniques that only generated errors and destruction. Partly it was true - this is evident, especially in the first two decades. On the other hand, we cannot deny that the story of Vesuvian archaeology in the $18^{\text {th }}$ century at Stabiae, as at Pompeii and Herculaneum, is also the history of the progressive establishment of a technique and of a working method which departed from previous practice and which slowly began to take shape both through the talent and vision of figures such as Weber and La Vega, and for the good sense of the Neapolitan court, which had the great merit of knowing how to revise its approach to antiquities from an initial vision tied to the antiquarian tradition of the humanistic approach to a more rigorous approach that laid the foundation of the birth of the future archaeological discipline.

\section{References}

1. Allroggen-Bedel A. Gli scavi borbonici nella villa S. Marco e le pitture staccatevi nel Settecento. La villa San Marco a Stabia. Napoli; Roma; Pompei, Centre Jean Bérard, École Française de Rome, Soprintendenza Archeologica di Pompei Publ., 1999, pp. 21-40 (in Italian).

2. Allroggen-Bedel A. Gli affreschi delle ville di Stabiae. Stabiae dai Borbone alle ultime scoperte. Castellammare di Stabia, Nicola Longobardi Editore Publ., 2001, pp. 51-57 (in Italian).

3. Allroggen-Bedel A. Gli scavi borbonici nelle ville stabiane: pitture antiche e gusto settecentesco. Stabia: storia e architettura: 250 anniversario degli scavi di Stabiae 1749-1999. Roma, L'Erma di Bretschneider Publ., 2002, pp. 101-108 (in Italian).

4. Ampolo C. La riscoperta della Magna Grecia. Magna Grecia: il Mediterraneo, le metropoleis e la fondazione delle colonie. Milano, Electa Publ., 1985, pp. 47-84 (in Italian).

5. Barbanera M. Storia dellarcheologia classica in Italia: dal 1764 ai giorni nostril. Bari, Editori Laterza Publ., 2015. 227 p. (in Italian). 
6. Barbet A.; Miniero P. (eds.). La villa San Marco a Stabia. Napoli-Roma-Pompei, Centre Jean Bérard, École Française de Rome, Soprintendenza Archeologica di Pompei Publ., 1999, 412 p. (in French and Italian).

7. Bonifacio G. Ufficio Scavi di Stabia. C. mare di Stabia: indagini archeologiche nell'area del pianoro di Varano. Rivista di Studi Pompeiani, 18. Roma, L'Erma di Bretschneider Publ., 2007, pp. 197-200 (in Italian).

8. Camardo D. La riscoperta di Stabiae negli scavi degli anni Cinquanta. Stabiae dai Borbone alle ultime scoperte. Castellammare di Stabia, Nicola Longobardi Editore Publ., 2001, pp. 69-72 (in Italian).

9. Camardo D. La Villa di Arianna a Stabiae. Stabiae dai Borbone alle ultime scoperte. Castellammare di Stabia, Nicola Longobardi Editore Publ., 2001, pp. 75-84 (in Italian).

10. Camardo D. La Villa del Pastore a Stabiae. Stabiae dai Borbone alle ultime scoperte. Castellammare di Stabia, Nicola Longobardi Editore Publ., 2001, pp. $93-96$ (in Italian).

11. Castaldi G. N. Della Regale Accademia Ercolanese dalla sua fondazione sinora con un cenno biografico de' suoi soci ordinari. Napoli, 1840. 280 p. (in Italian).

12. Ciardiello R. Larcheologia dei Borbone nella cultura europea. I Borbone di Napoli. Sorrento, Franco Di Mauro Editore Publ., 2009, pp. 137-149 (in Italian).

13. Conti A. Storia del restauro e della conservazione delle opere d'arte. Milano, Electa Publ., 1973. 286 p. (in Italian).

14. D'Alconzo P. Picturae excisae. Conservazione e restauro dei dipinti ercolanesi e pompeiani tra XVIII e XIX secolo. Roma, L'Erma di Bretschneider Publ., 2002. 152 p. (in Italian).

15. d'Orsi L. Gli scavi di Stabiae. Giornale di scavo. Ministero per i Beni Culturali ed Ambientali, Soprintendenza Archeologica di Pompei, Monografie, vol. 11. Castellammare di Stabia, Nicola Longobardi Editore Publ., 1996. 526 p. (in Italian).

16. Ferrara A. La Villa San Marco a Stabiae. Stabiae dai Borbone alle ultime scoperte. Castellammare di Stabia, Nicola Longobardi Editore Publ., 2001, pp. 99-104 (in Italian).

17. Gardelli P.; Butyagin A.; Chistov D.; Ershova A.; Fiore I. Relazione preliminare sulle due campagne di scavo, restauro e rilievo 2010 e 2011 promosse dal Museo Statale Ermitage / Fondazione RAS presso il sito di Villa Arianna a Stabiae. Rivista di Studi Pompeiani, 22. Roma, L'Erma di Bretschneider Publ., 2011, pp. 209-216 (in Italian).

18. Gardelli P.; Butyagin A. Stabiae, Villa Arianna. Relazione sulle due campagne di scavo e restauro 2012 / 2013 condotte dal Museo Statale Ermitage / Fondazione RAS. Rivista di Studi Pompeiani, 24. Roma, L'Erma di Bretschneider Publ., 2013, pp. 135-139 (in Italian).

19. Gardelli P.; Ariano C. Un mosaico ritrovato proveniente dagli scavi settecenteschi di Stabiae. Atti del XXII Colloquio Associazione Italiana per lo Studio e la Conservazione del Mosaico. Tivoli, Scripta Manent Publ., 2016, pp. 651-662 (in Italian).

20. Howe T. N.; Gleason K.; Sutherland I. The Excavation and Study of the Garden of the Great Peristyle of the Villa Arianna, Stabiae, 2007-2012. Quaderni di Studi Pompeiani, 7. Castellammare di Stabia, Nicola Lon-gobardi Editore Publ., 2017 (in press).

21. Howe T. N.; Gleason K.; Sutherland I. Stabiae, Villa Arianna: scavi e studi nel giardino del Grande Peristilio, 2007-2011. Rivista di Studi Pompeiani, 22. Roma, L’Erma di Bretschneider Publ., 2011, pp. 205-209 (in Italian).

22. Pagano M. I Diari di scavo di Pompei, Ercolano e Stabia di Francesco e Pietro La Vega (1764-1810). Roma, L'Erma di Bretschneider Publ., 1997, 190 p. (in Italian).

23. Pagano M.; Prisciandaro R. Studio sulle provenienze degli oggetti rinvenuti negli scavi borbonici del Regno di Napoli: una lettura integrata, coordinata e commentata della documentazione, 2 vols. Castellammare di Stabia, Nicola Longobardi Editore Publ., 2006 (in Italian).

24. Parslow C. C. Rediscovering Antiquity: Karl Weber and the Excavation of Herculaneum, Pompeii and Stabiae. Cambridge, Cambridge University Press Publ., 1995. 416 p.

25. Rossano P. Le esplorazioni settecentesche allombra del Vesuvio. Stabiae dai Borbone alle ultime scoperte. Castellammare di Stabia, Nicola Longobardi Editore Publ., 2001, pp. 17-22 (in Italian).

26. Rossignani M. P. Saggio sui restauri settecenteschi ai dipinti di Ercolano e Pompei, Contributi dell'Istituto di Archeologia, serie 3a, vol. 1. Milano, Pubblicazioni dell'Università del Sacro Cuore Publ., 1967, pp. 7-134 (in Italian).

27. Ruffo F. Sulla topografia dell'antica Stabiae. Osservazioni sulla Villa San Marco e sul cosiddetto impianto urbano alla luce delle recenti indagini archeologiche (2008-2009). Oebalus: Studi sulla Campania nell'Antichità, vol. 4. Roma, Bardi Editore Publ., 2009, pp. 235-271 (in Italian). 
28. Ruffo F. L'insula sud-occidentale del cosiddetto "impianto urbano" di Stabiae. Nuovi dati dalla recente campagna di scavo (2009). Oebalus: Studi sulla Campania nell'Antichità, vol. 5. Roma, Bardi Editore Publ., 2010, pp. 177-239 (in Italian).

29. Ruggiero M. Degli Scavi di Stabia dal MDCCXLIX al MDCCLXXXII. Notizie raccolte e pubblicate da Michele Ruggiero. Napoli, M. de Rubertis, 1881. 366 p. (in Italian).

30. Sodo A. M. I rinvenimenti recenti: nuovi ambienti in luce a Villa Arianna. Stabiae dai Borbone alle ultime scoperte. Castellammare di Stabia, Nicola Longobardi Editore Publ., 2001, pp. 85-88 (in Italian).

31. Sodo A. M. I rinvenimenti recenti: le sostruzioni della Villa del Pastore. Stabiae dai Borbone alle ultime scoperte. Castellammare di Stabia, Nicola Longobardi Editore Publ., 2001, pp. 97-98 (in Italian).

32. Varone A. I graffiti della villa di San Marco a Stabia. La villa S. Marco a Stabia. Napoli; Roma; Pompei, Centre Jean Bérard, École française de Rome, Soprintendenza Archeologica di Pompei Publ., 1999, pp. 345362 (in Italian).

33. Winckelmann J. J. Lettera al Consigliere Bianconi Art. X, Notizie sopra altre antichità di Pompeja, di Stabbia, di Pesto e di Caserta. Opere di G. G. Winckelmann, vol. 7. Prato, Fratelli Giachetti Publ., 1831, pp. 83-89 (in Italian).

34. Winckelmann J. J. Lettera sulle scoperte di Ercolano al Sig. Conte Enrico di Brühl. Opere di G. G. Winckelmann, vol. 7. Prato, Fratelli Giachetti Publ., 1831, pp. 127-236 (in Italian).

Title. Stabiae and the Beginning of European Archaeology: From Looting to Science.

Author. Paolo Gardelli - Ph. D. student. Ludwig-Maximilian University of Munich, Institut für Klassische Archäologie, Katharina-von-Bora-Straße 10, 80333 München, Germany; executive coordinator and archaeologist. Restoring Ancient Stabiae Foundation, Via Solaro, 13, 80053 Castellammare di Stabia, Italy. pa.gardelli@ gmail.com; paolo.gardelli@campus.lmu.de

Abstract. The most widespread preconception, one that sees the entire period of Bourbon archaeology at Herculaneum, Pompeii and Stabiae as a time of primitive and brutal techniques that only generated errors and destruction. Partly it was so - this is evident, especially in the first phase. But, on the other hand, we cannot deny that the story of Vesuvian archaeology in the $18^{\text {th }}$ century is also the history of the progressive establishment of a technique and of a working method which departed from previous practice and which slowly began to take shape both through the talent and vision of figures such as Karl Weber and Francesco La Vega, and for the good sense of the Neapolitan court, which had the great merit of knowing how to revise its approach to antiquities, from an initial vision tied to the antiquarian tradition of the humanistic approach to a more rigorous approach that laid the foundation for the birth of the future archaeological discipline. In fact, it marks the beginning of a serious interest in the Roman past, the recovery of the Roman past, and the accurate recovery of the Roman past. The frescoes which were "stolen" from the walls of Stabiae in the $18^{\text {th }}$ century are still some of the best preserved. The plans done under extremely difficult circumstances by Karl Weber are some of the best ever done, and the records which they left have allowed scholars in the last decades to trace the actual preserved remains with their original locations.

Keywords: the Bay of Naples; history of archaeology; Bourbon excavations; the Vesuvian area; Stabiae; Ancient Roman elite maritime villas.

Название статьи. Стабии и начало европейской археологии: от грабительских раскопок к научным исследованиям.

Сведения об авторе. Гарделли Паоло - аспирант. Мюнхенский университет имени Людвига и Максимилиана, Институт классической археологии, ул. Катарины фон Бора 10, 80333 Мюнхен, Германия; исполнительный координатор и специалист-археолог. Фонд реставрации древних Стабий, Виа Соларо, 13, 80053 Кастелламмаре ди Стабиа, Италия. pa.gardelli@gmail.com; paolo.gardelli@campus.lmu.de

Аннотация. Наиболее широко распространено представление о том, что на протяжении всего правления Бурбонов раскопки в Помпеях, Геркулануме и Стабиях были примитивны и отличались применением грубых приемов, последствиями которых становились лишь разрушения и ошибки. Это, без сомнения, отчасти так, особенно в самом начале. С другой же стороны, нельзя отрицать, что история везувианских раскопок XVIII в. - это в то же время и история постепенного поиска технических приемов и методов, коренным образом отличных от предшествующих практик. В основу формирования археологии как научной дисциплины было положено ее видение такими талантливыми и прозорливыми людьми, как Карл Вебер и Франческо Ла Вега. Также это было обусловлено здравомыслием Неаполитанского двора, огромной заслугой которого стало понимание необходимости пересмотра отноше- 
ния к древностям - от первоначальной традиции антикварианизма, идущей от гуманистов прошлого, требовался переход к более строгим подходам и взгляду на археологию. Фактически, в это время обозначились начала серьезного интереса к римскому прошлому, стремление к его воссозданию, причем к точному воссозданию. Фрески, «похищенные» в XVIII в. со стен стабианских вилл, сегодня - в числе наилучшим образом сохранившихся памятников. Планы, в невероятно трудных условиях составленные Карлом Вебером - одни из лучших среди когда-либо создававшихся, а записи, оставленные предшественниками современных исследователей, за минувшие три десятилетия позволили сопоставить планы с сохранившимися по сей день руинами и выявить первоначальное расположение строительных остатков.

Ключевые слова: Неаполитанский залив; история археологии; раскопки при Бурбонах; Везувианская область; Стабии; приморские виллы древнеримской знати. 


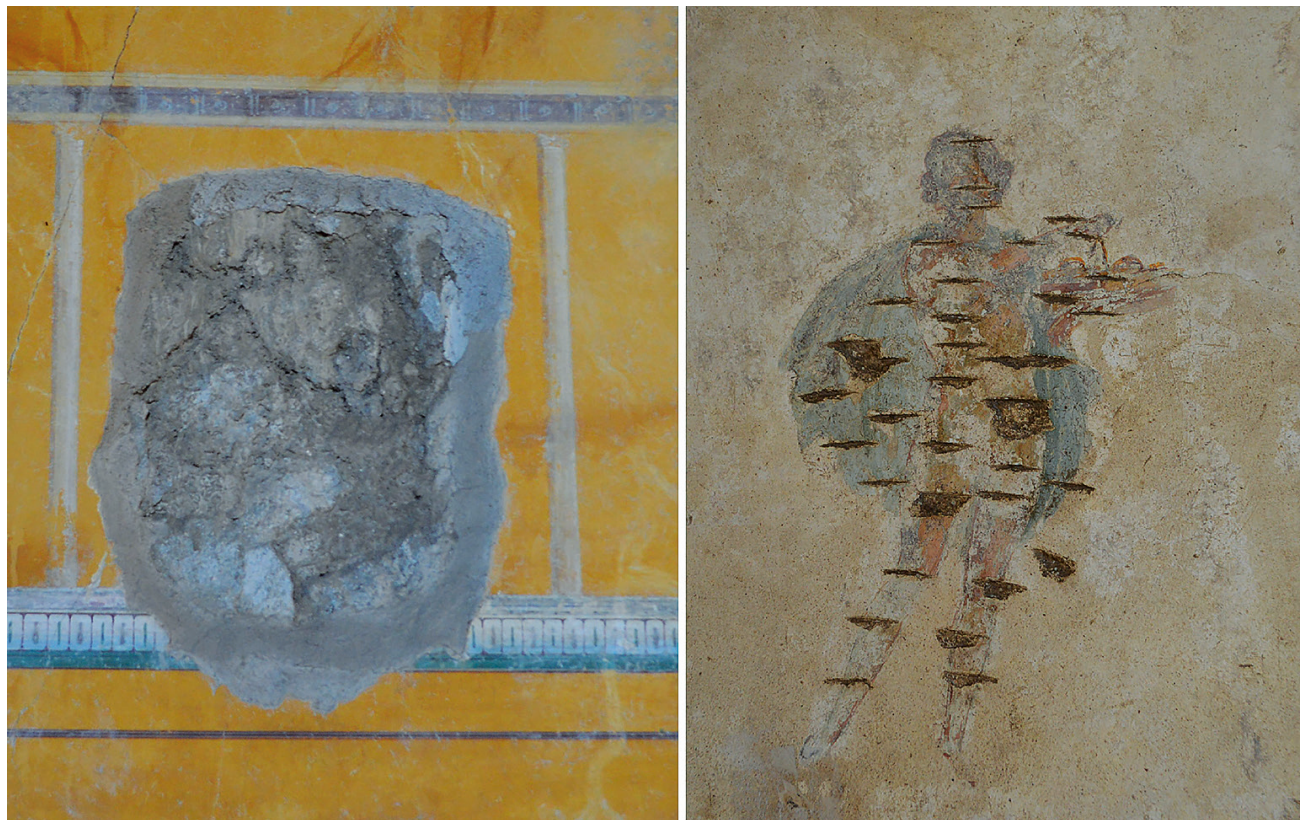

Ill.97. On the left, the void in the wall left by the 18th century excavators after stripping off the painting; on the right, intentional destruction of the wall decoration, Villa Arianna, Stabiae. With the permission of the Ministero dei Beni e delle Attivitá Culturale e del Turismo - Sopritendenza Pompei. All rights are reserved.
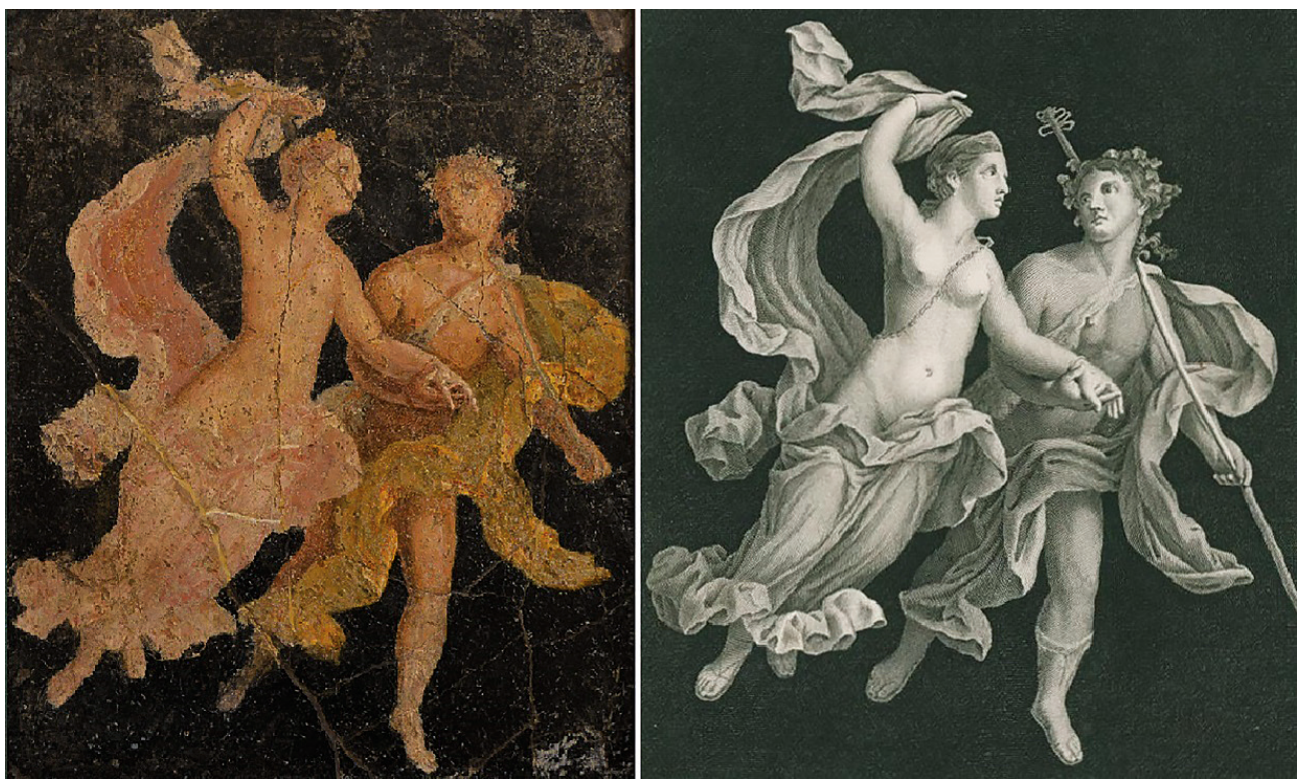

Ill.98. On the left, Ariadne and Dionysus in flight, from the atrium of Villa Arianna (MANN 9136); on the right, the engraving of the same painting published in 4th volume of "Le Antichità di Ercolano esposte". With the permission of the Ministero dei Beni e delle Attivitá Culturale e del Turismo - Museo Archeologico Nazionale di Napoli. All rights are reserved. 


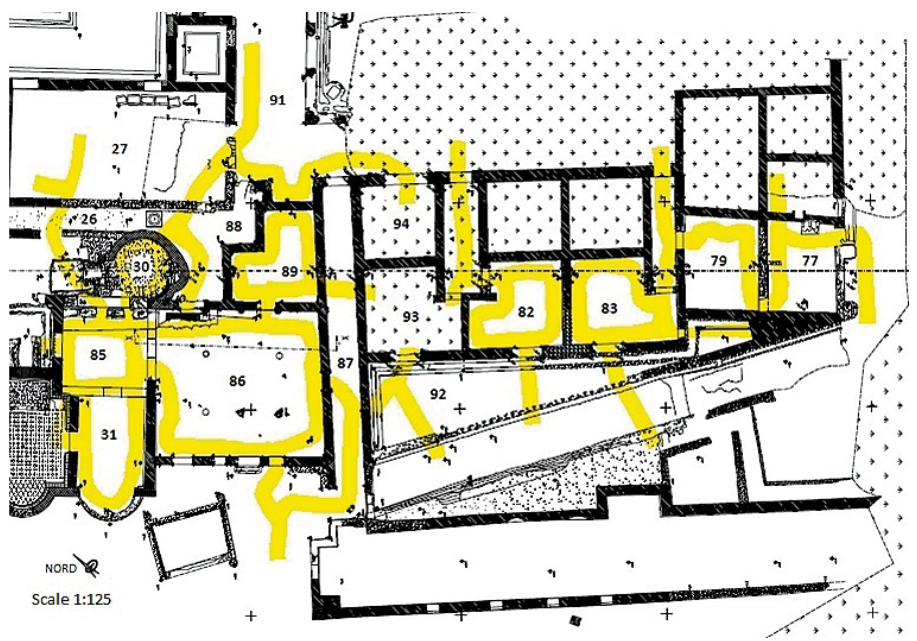

Ill. 99. The route of trenches made by the excavators in the '700s in the sectors of the Square Peristyle and of the Thermal Quarter of Villa Arianna, Stabiae (plan by G. Di Nola, V. Sabini, P. Gardelli). With the permission of the Ministero dei Beni e delle Attivitá Culturale e del Turismo Sopritendenza Pompei. All rights are reserved.

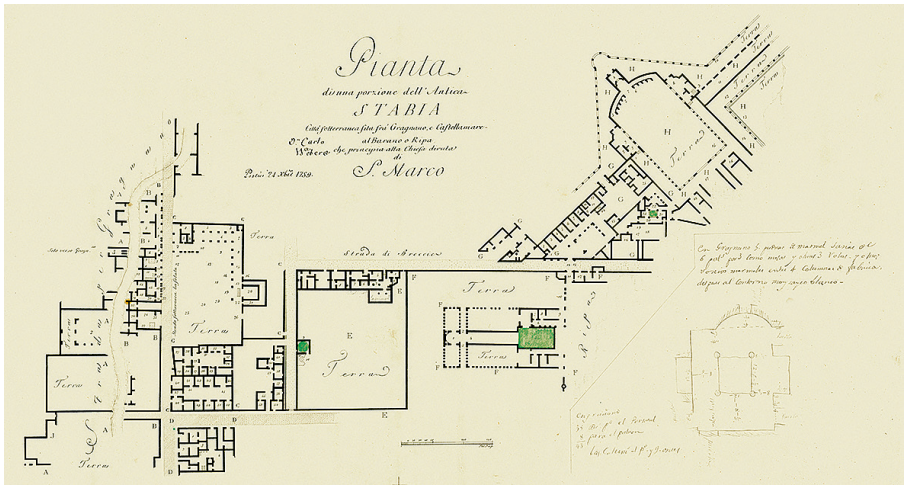

Ill. 100. The plans of Villa San Marco and of the urban settlement of Stabiae drawn by Weber in 1759 (published by Michele Ruggiero [29, Tav. I])

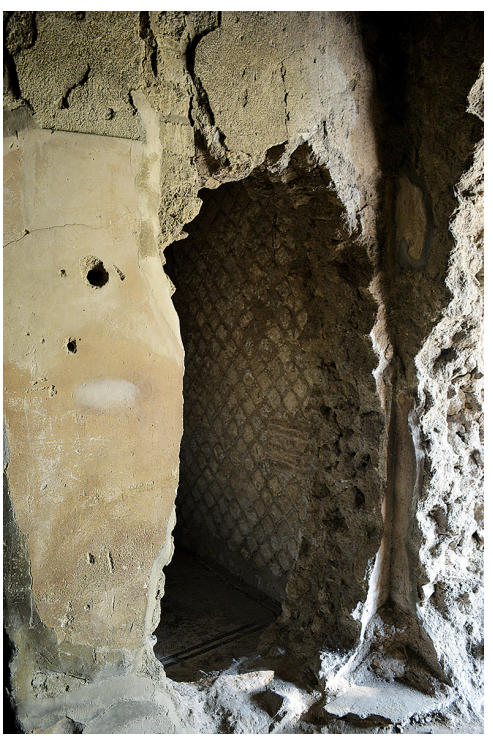

Ill. 101. Breach made by the excavators in the wall between rooms 26 and 27 in Villa San Marco, Stabiae. With the permission of the Ministero dei Beni e delle Attivitá Culturale e del Turismo - Sopritendenza Pompei. All rights are reserved. 